Egypt. Acad. J. biolog. Sci., 2 (2): 179-185 (2009)

Email: egyptianacademic@yahoo.com

Received: 30/11/2009
A. Entomology

ISSN: 1687-8809

www.eajbs.eg.net

\title{
Abundance of some potato homopterous pests as affected by potassium fertilization level
}

\author{
Mohamed A. El-Gindy; Rasha M. El-Refaey and Eftkhar E. Abou Hatab \\ Plant Protection Research Institute, Agricultural Research Center, Ministry of \\ Agriculture, Egypt.
}

\section{ABSTRACT}

Experiments were conducted during potato winter seasons of 2007/08 and 2008/09 at Dakahlia, Egypt. Four potassium fertilization levels (0, 100, 150 and 200 $\mathrm{kg} / \mathrm{fed}$ ) were applied to clarify their effects on the population density of Myzus percicae (Sulzer), Aphis gossypii Glover, Aphis craccivora Koch, Bemisia tabaci (Gennadius) and Empoasca sp. in potato fields. The obtained results showed that the highest population densities of these pests occurred at no potassium fertilization (control) followed by $100 \mathrm{~kg} / \mathrm{fed}$ and $150 \mathrm{~kg} / \mathrm{fed}$, respectively. The lowest population densities were recorded at $200 \mathrm{~kg} /$ fed treatment. A. gossypii and $M$. persicae were the most affected pests by potassium fertilization. A. craccivora and Empoasca sp. were affected in relatively moderate way. $B$. tabaci was the least affected one. On the other hand, epidermal thickness of potato leaves was significantly increased by fertilization level increase.

Keywords: Potassium fertilization, potato, Myzus percicae, Aphis gossypii, Aphis craccivora, Bemisia tabaci, Empoasca sp. abundance.

\section{INTRODUCTION}

Potato, Solanum tuberosum L. is the world's most important food crop with annual production of nearly 300 million tons produced by more than 12 million hectares (Martin et al. 1990).

Homopterous pests have great economic importance to potato plants. They cause serious damage directly by sucking plant sap or indirectly by transmission of virus and mycoplasma diseases (El-Nahal et al., 1977; Aboul-Ata, 1983; Hegab et al., 1987 and El-Gindy, 2002). These pests interferes with leaves physiology by mechanically plugging the phloem and xylem vessels, causes stunting, curling and browning of the leaves (Borror et al., 1981).

Fertilization had an important role on homopterous pest infestations; where the high rates of potassium reduced the population density of these pests on cereal, legumes and maize plants (Hegab, 2001; El-Gindy, 2002 and El-Gindy, 2006).

The present work aimed to evaluate the relation between some homopterous pests infesting potato plants and the epidermal thickness of potato leaves in response to different potassium fertilization levels on potato plants.

\section{MATERIALS AND METHODS}

This experiment was conducted during two potato seasons of 2007/08 and $2008 / 09$. Observations started from the $1^{\text {st }}$ week of Oct. to the $2^{\text {nd }}$ week of Jan. (harvest time). An area about $1050 \mathrm{~m}^{2}$ was chosen to carry out this investigation in ElMansoura Distract, Dakahlia Governorate (Esponta potato variety). 
The area was divided into 12 plots, arranged as completely randomized design. Nine plots were fertilized with levels of fertilization as 100,150 and $200 \mathrm{~kg} / \mathrm{fed} \mathrm{(3}$ plots/ level as replicates) and three plots were no fertilized (as control). Potassium fertilization (as potassium sulphate $48 \% \mathrm{~K}_{2} \mathrm{O}$ ) was added after five weeks early in the growing season.

Weekly samples of 10 leaves/ plot were picked at random from the three levels of the plants (low, mid and upper). Each sample was kept in tight closed paper bag and transferred to the laboratory in the same day for inspection by the bionocular microscope. The homopterous pest, Myzus percicae (Sulzer), Aphis gossypii Glover, Aphis craccivora Koch, Bemisia tabaci (Gennadius) and Empoasca sp. were counted and recorded. All plots received normal agricultural practices and were kept free of any insecticide treatment.

* Effect of fertilization on the thickness of potato epidermal cells:

Samples of potato leaves were collected and cleaned up with tap water, cut into suitable parts, fixed in formalin, acetic acid, alcohol (F.A.A.) solution for at least 36 hours, dehydrated with n-butyl alcohol, infiltrated and embedded in pure paraffin wax (M.P.56 - 58 ${ }^{\circ}$ C) (Johancen, 1940). Sectioning at thickness of 14 micron was performed by using a rotatory microtome. Paraffin ribbons were mounted on thin slides and stained with safranin and light green. Stained sections were mounted in Canada balsam then examined microscopically. The epidermal cell thickness was measured by ocular micrometer.

Data were subjected to correlation and simple regression using Costat (1990) soft ware.

\section{RESULTS}

The effect of four levels of potassium fertilization $(0,100,150$ and 200 $\mathrm{kg}$ /feddan) on the population density of $M$. percicae, A. gossypii, A. craccivora, $B$. tabaci and Empoasca sp. infesting potato plants were studied during the two successive seasons of 2007/08 and 2008/09.

Obtained data illustrated in Figures (1 and 2$)$ showed that the highest population densities of these pests occurred without any potassium fertilization (control) followed by using of 100 and $150 \mathrm{~kg} / \mathrm{fed}$, respectively. Lowest population densities were recorded when $200 \mathrm{~kg} /$ fed were used.

A. gossypii and $M$. persicae were the most affected pests by potassium fertilization, where the correlation coefficient values between their populations and potassium fertilization were negative and highly significant during the first $(\mathrm{r}=$ $-0.997^{* *}$ and $\left.-0.995^{* *}\right)$ and second $\left(\mathrm{r}=-0.998^{* *}\right.$ and $\left.-0.991^{* *}\right)$ seasons (Table, 1$)$. A. craccivora and Empoasca sp. were affected by the potassium fertilization with relatively moderate values; where the correlation coefficient values between their populations and potassium fertilization were negative and significant during the first $\left(\mathrm{r}=-0.989^{*}\right.$ and $\left.-0.988^{*}\right)$ and second $\left(\mathrm{r}=-0.969^{*}\right.$ and $\left.-0.988^{*}\right)$ seasons. B. tabaci was the least affected pest by potassium fertilization; where the calculated r-values were $0.971^{*}$ and $-0.890^{\text {ns }}$ during the first and second season, respectively. 


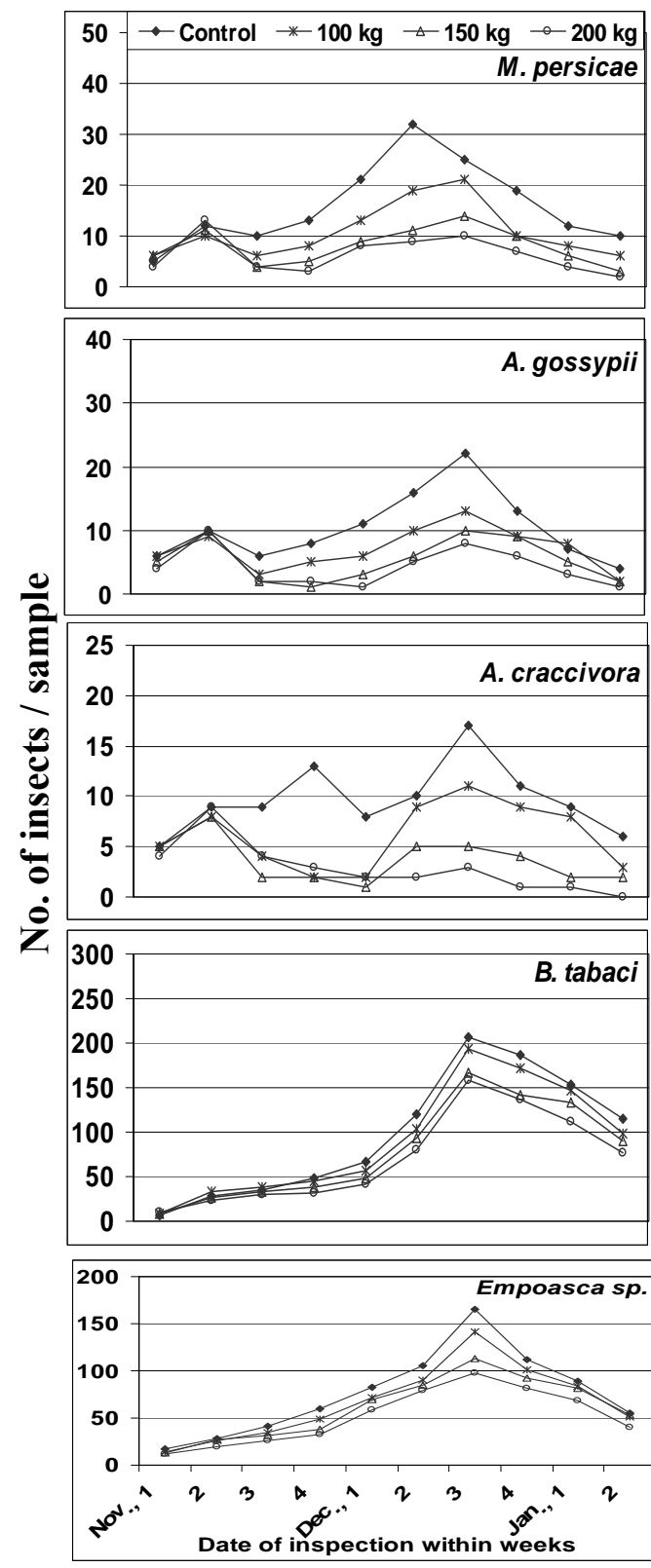

2007/08
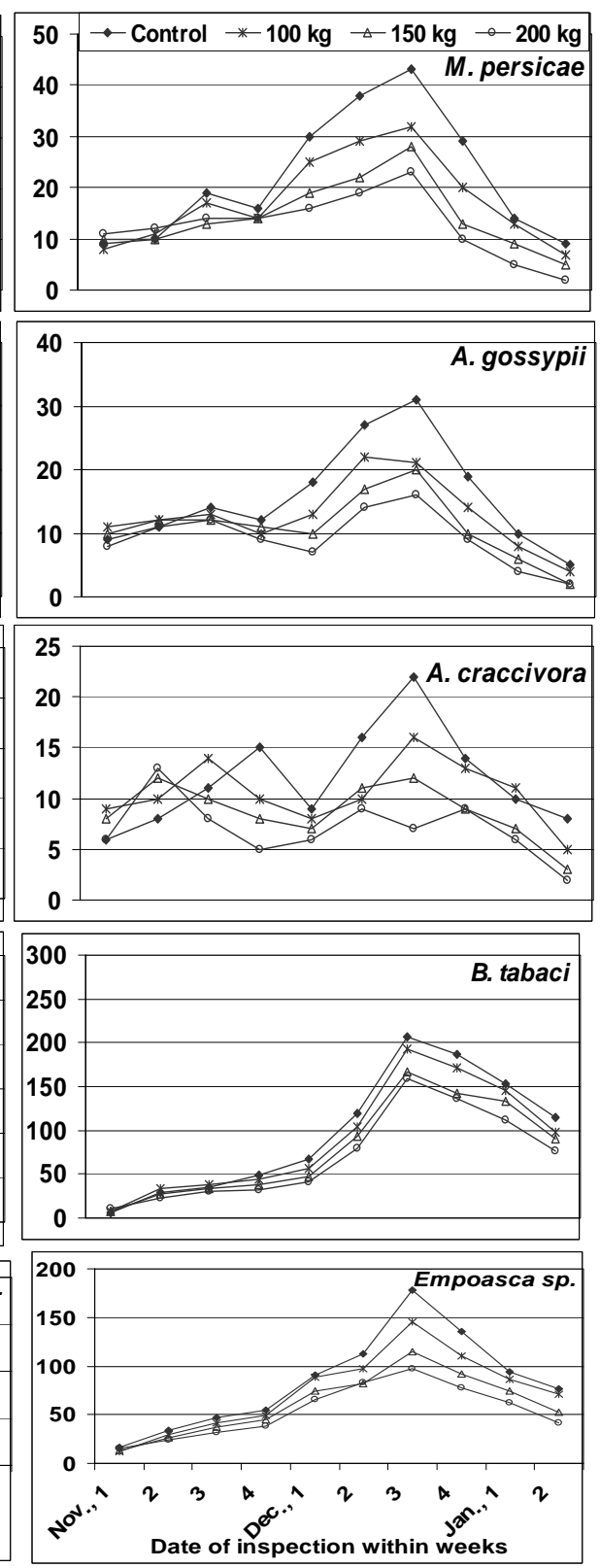

2008/09

Fig. 1: Population fluctuations of homopterous pests infesting potato plants at different levels of potassium fertilization during 2007/08 and 2008/09 seasons. 

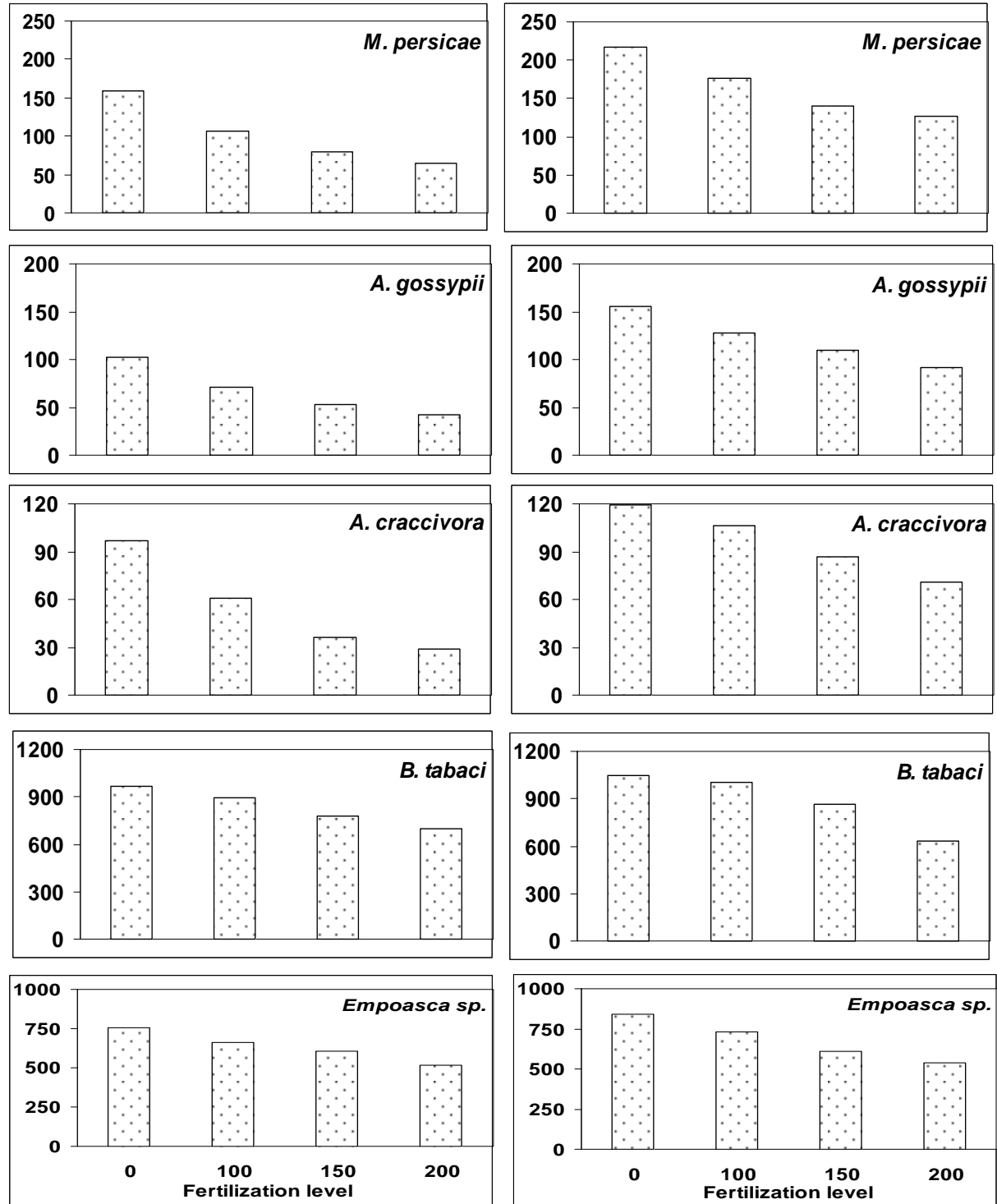

2007/08

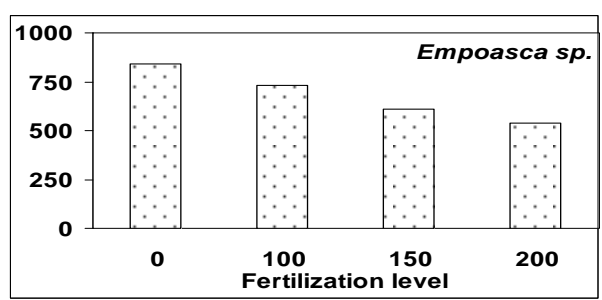

2008/09

Fig. 2: Total number of homopterous pests infesting potato plants at four potassium fertilization levels $(0,100,150,200 \mathrm{~kg} /$ fed.) during 2007/08 and 2008/09 seasons.

Table 1: Correlation coefficient and regression values between homopterous pests' populations and potassium fertilization levels in potato fields during 2008 and 2009 seasons.

\begin{tabular}{|l|c|c|c|c|c|c|}
\hline \multirow{2}{*}{ Homopterous pest } & \multicolumn{3}{|c|}{$2007 / 08$} & \multicolumn{3}{c|}{$2008 / 09$} \\
\cline { 2 - 7 } & $\mathrm{r}$ & $\mathrm{a}$ & $\mathrm{b}$ & $\mathrm{r}$ & $\mathrm{a}$ & $\mathrm{b}$ \\
\hline M. persicae & $-0.995^{* *}$ & 157.0 & -0.49 & $-0.991^{* *}$ & 218.0 & -0.47 \\
\hline A. gossypii & $-0.997^{* *}$ & 102.0 & -0.31 & $-0.998^{* *}$ & 157.0 & -0.32 \\
\hline A. craccivora & $-0.989^{*}$ & 95.8 & -0.36 & $-0.969^{*}$ & 123.0 & -0.24 \\
\hline B. tabaci & $-0.971^{*}$ & 987.0 & -1.35 & -0.890 & 1105.0 & -1.94 \\
\hline Empoasca sp. & $-0.988^{*}$ & 765.0 & -1.16 & $-0.988^{*}$ & 854.0 & -1.55 \\
\hline
\end{tabular}

The obtained data revealed that there is a relationship between the tested pests densities and potassium fertilization levels. However, each increase in potassium fertilization level results a reduction in each pest population density. 
As shown in Figures (3 and 4), epidermal thickness increased as the potassium fertilization level increased. At the levels of $0,100,150$ and $200 \mathrm{~kg} /$ feddan the epidermal thickness was $2.50,3.33,3.60$ and 4.45 micron, respectively.

Statistically, epidermal thickness was significantly increased by potassium fertilization level increase. Each increase of potassium fertilization by $1 \mathrm{~kg} /$ feddan epidermal thickness increases by 0.01 microns (Fig. 3).

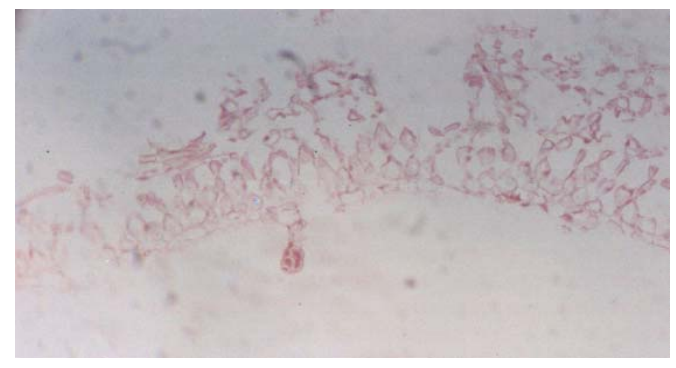

A

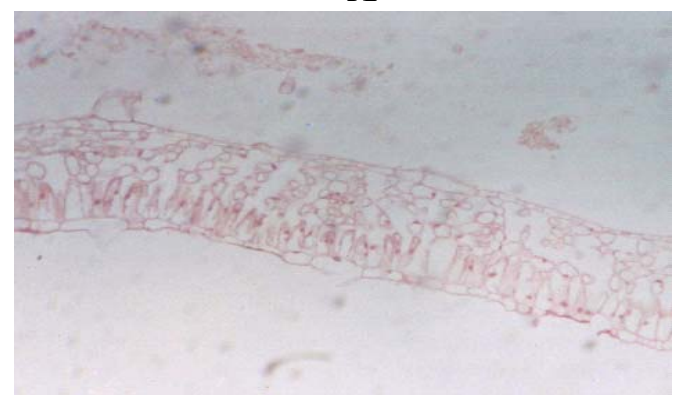

C

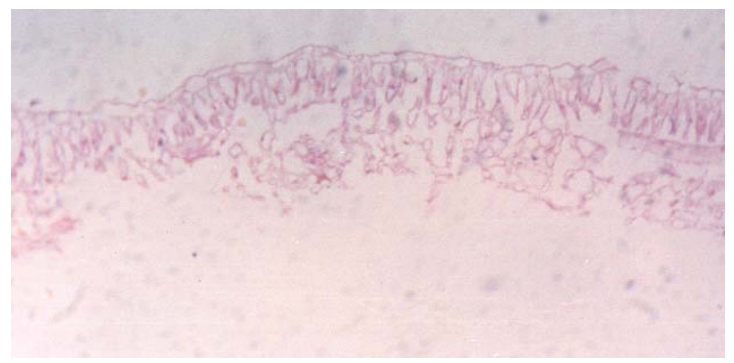

B

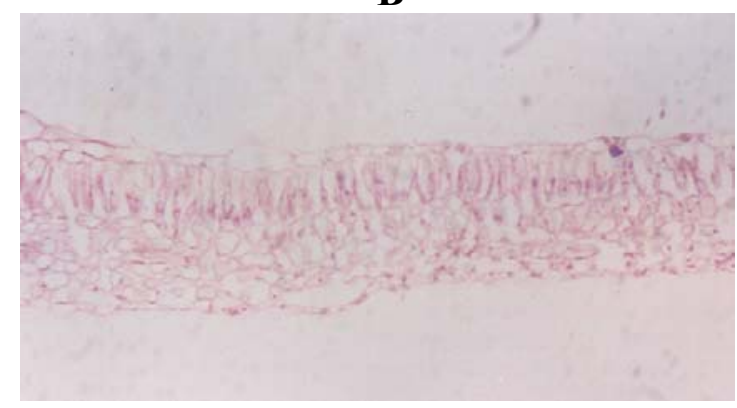

D

Fig. 3: Epidermal thickness of potato leaves under 0 (A), 100 (B), 150 (C) and 200 (D) kg potassium fertilization / feddan treatments.

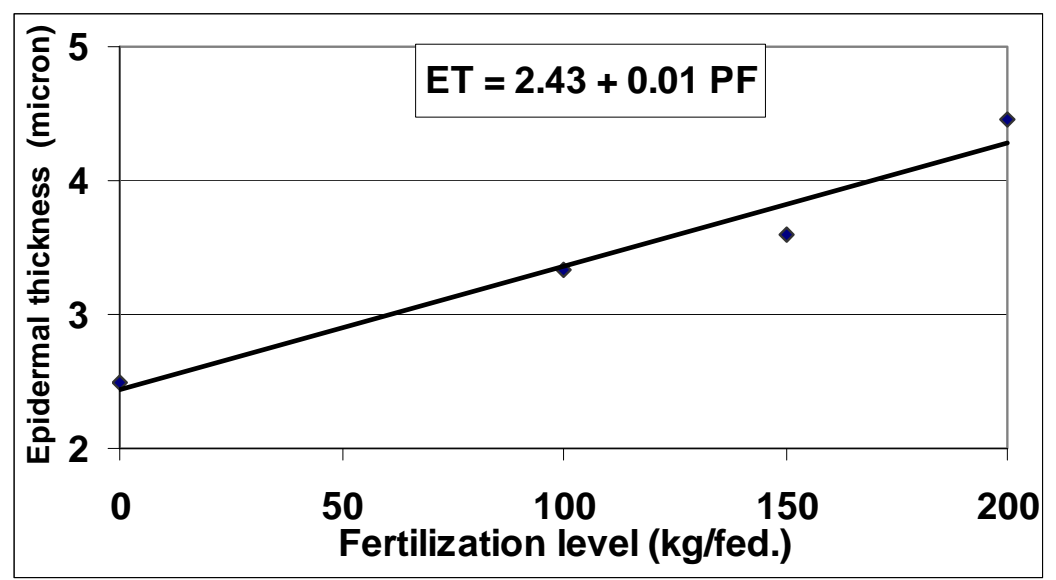

Fig. 4: Effect of potassium fertilization (PF) on the epidermal thickness (ET) of potato plants.

\section{DISCUSSION}

The present results revealed that potato plants at the studied location was infested with M. percicae, A. gossypii, A. craccivora, B. tabaci and Empoasca sp.. These pests were recorded on potato plants by Parihar et al. (1996) and Kuroli (2001).

On another hand, M. percicae, A. gossypii, A. craccivora, B. tabaci and Empoasca sp. populations were most at zero potassium fertilization in comparison with 100,150 and $200 \mathrm{~kg} /$ feddan, respectively. These results are in same line of 
Hegab (2001), El-Gindy (2002), El-Gindy (2006) and El-Gindy et al. (2006). They mentioned that as the increase of potassium fertilization the population density of many homopterous pests decreased. The present results revealed that population density of the tested pests could be predicted according to the potassium fertilization level.

Results concluded that increase of potassium fertilization level increase the thickness of epidermal leaves. This consequently suppressed the ability of homopterous insect mouth parts to pierce the leave cells of potato plants to feed. Therefore, the potassium fertilization could be recommended as agent of integrated pest management against homopterous pests.

Similar conclusion was obtained by Hegab (2001), El-Gindy (2002), El-Gindy (2006) and El-Gindy et al. (2006). They found that potassium fertilization increased the thickness of epidermal leaves and suppressed the infestation of several piercing and sucking insect pests on cereal, legumes and maize plants.

\section{REFERENCE}

Aboul-Ata, A.E. (1983). Auchenorrhynchan insects of certain gramineous crops and the occurrence of leafhopper-borne disease in Egypt. Ph.D. Thesis, Fac. Agric., Cairo Univ.

Borror, K.J.; Delong, D. M. and Triplehonrn, C.A. (1981). An introduction to the study of insects. Saunders College Publishing, Holt, Rinehart and Winston, pp. 281-285.

El-Gindy, M. A. (2002). Studies on certain homopterous insect vectors of plant pathogenic diseases. Ph.D. Thesis, Fac. of Agri., Zagazig Uni., 274 p.p..

El-Gindy, M. A. (2006). Susceptibility of three maize cultivars to leaf hopper infestations and effect of potassium fertilizers on leaf hoppers. Egypt. J. of Appl. Sci., 21 (10A) 302-314.

El-Gindy, M. A.; Ibraheem, M. M. A. and Megahed, H. E. (2006). Susceptibility of three maize cultivars to aphid infestation and effect of potassium fertilizer levels on aphid. J. Agric. Sci., Mansoura Univ., 31 (1): 457-463.

El-Nahal, E.; Ammar, D. and El-Bolok, M. M. (1977). Survey and population density of leafhoppers, planthoppers and froghoppers (Homoptera: Auchenorrhyncha) on field and vegetable crops at Giza. Bull. Soc. ent. Egypt. 61: 99-108.

Hegab, A. H.; Kelany, I. M. and El-Deeb M. A. (1987). Seasonal abundance of leafhoppers and plant hoppers (Homoptera: Auchenorrhyncha) infesting maize plants in newly reclaimed sandy areas at Salhia district, Egypt. Minia J. Agric. Res. \& Dev., 9 (2): 897-910.

Hegab, I.M.S. (2001). Studies on certain insect vectors of plant pathogenic agents. Ph. D. Thesis, Fac. Agric., Zagazig Univ.

Johancen, D. A. (1940). Plant microtechnique. MC. Graw-Hill Book Company. New York.

Kuroli, G. (2001). Change of population density of the leafhoppers Empoasca solani Curtis and E. decipiens Paoli feeding on potatoes. Növényvédelem, 37: 225-230.

Martin, J.H.; Leonard, W. L. L. and Stamp, D. L. (1990). Principles of field crop production. $3^{\text {rd }}$ ed., Macmillan Publishing Co., Inc. New York, pp.898-932.

Parihar, S.B.S.; Verma, K. D. and Malik, K. (1996). Evaluation of potato genotypes against Aphis gossypii damage. Insect Environ. 2: 48-49. 


\section{ARABIC SUMMARY}

$$
\begin{aligned}
& \text { وفرة بعض آفات البطاطس متثابهة الأجنحة وتأثرها بمستوى التسميد البوتاسي }
\end{aligned}
$$

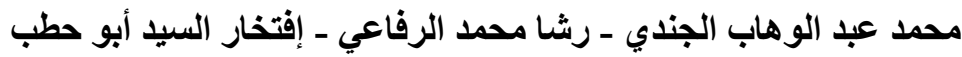

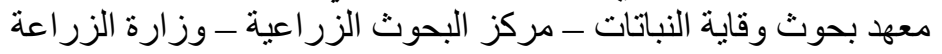

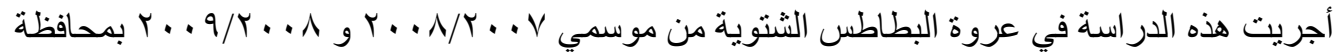

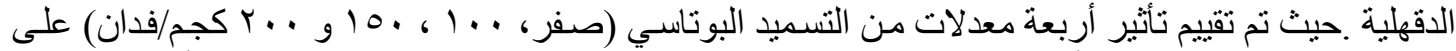

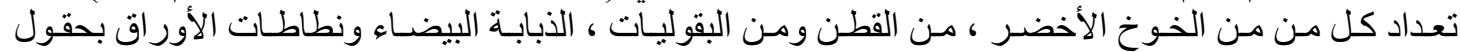

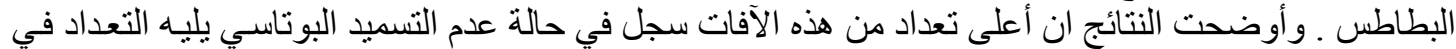

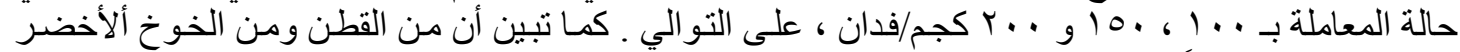

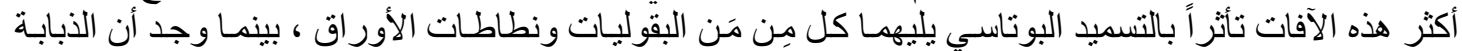

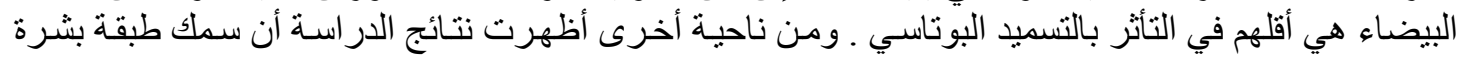

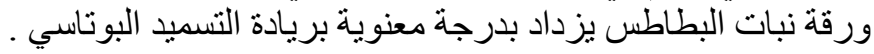

